\title{
Karakterisasi Dan Identifikasi Molekuler Fusan Hasil Fusi Protoplas Interspesies Chlorella pyrenoidosa dan Chlorella vulgaris Menggunakan 18SrDNA
}

\author{
${ }^{1}$ Asih Rismiarti, ${ }^{1}$ Hermin Pancasakti Kusumaningrum, ${ }^{3}$ Muhammad Zainuri \\ dan ${ }^{2}$ Sri Pujiyanto \\ ${ }^{1}$ Laboratorium Genetika \\ ${ }^{2}$ Laboratorium Mikrobiologi \\ Departemen Biologi, Fakultas Sains dan Matematika, Universitas Diponegoro, Semarang \\ Jln Prof. Soedarto, SH,Semarang,50275, Telp: (024)7474754; Fax (024) 76480923 \\ ${ }^{3}$ Laboratorium Kelautan \\ Departemen Kelautan, Fakultas Perikanan dan Ilmu Kelautan, Universitas Diponegoro \\ Tembalang, Semarang - 50275 \\ Telepon (024) 7474754; Fax. (024) 76480690 \\ Email : asih.rismiarti@gmail.com
}

\begin{abstract}
Chlorella pyrenoidosa is a unicellular green algae that grows in fresh water with carotenoids consisting of $\beta$-carotene, $\alpha$-carotene, anthaxanthin, neoxanthin, zeaxanthin and lutein. $C$. vulgaris usually it lives in sea water with carotenoids, chlorophyll, tocopherol, ubiquinone and proteins. The quality of them is improved by protoplast fusion and identified further using moleculer analysis. This study aims to find out the characterization and identification of molecular fusan that is obtained from interspecies C. pyrenoidosa and C. vulgaris protoplast fusion process using 18SrDNA. Both C. pyrenoidosa and C. vulgaris are combined by protoplast fusion and then they were performed the isolation of DNA with CTAB modification method, followed by PCR gradient using primers 18S Chlorella and performed DNA sequencing. The result show that there are different characters between masterplan and fusan based on growth of fresh water and sea water medium. The success frequency of fusan as a result from protoplast fusion in the fresh water media is $21 \%$ and $6 \%$ for sea water medium. The results of the alignment between fresh water fusan and C. vulgaris masterplan from GeneBank shows that the base sequence homology is $93 \%$ C. pyrenoidosa masterplan from GeneBank is $90 \%$. The result of molecular identification towards the sequence of fresh water fusan bases shows that there is a kinship relationship with the masterplan of C. pyrenoidosa 18S Chlorella and Chlorosphaera klebsii microalgae compared with some other species from Chlorophyta group with similarity value as many as $91 \%$. It shows that the high variety genetic is based on variations of the base sequence and has a kinship with other species in the Chlorophyta group.
\end{abstract}

Keywords : Chlorella pyrenoidosa, Chlorella vulgaris, Protoplast Fusion, DNA Sequensing, 18SrDNA.

\section{INTRODUCTION}

Mikroalga adalah tumbuhan tingkat rendah yang memiliki klorofil, dapat digunakan untuk melakukan proses fotosintesis. Chlorella pyrenoidosa merupakan mikroalga yang memiliki kandungan protein $60 \%$, karbohidrat dan lemak 20\% (Asni, 2000). $\quad$ C. vulgaris memiliki kandungan gizi berupa protein $55 \%$, serat $5,8 \%$, lipid 10,2\% dan karbohidrat 23,2\% (Maruyama, 1997). $\quad C$. pyrenoidosa dan $C$. vulgaris memiliki karakter yang berbeda-beda. Perbedaan utamanya adalah $C$. pyrenoidosa biasa hidup di air tawar, sedangkan $C$. vulgaris hidup di air laut. Keunggulan dari keduanya dapat ditingkatkan melalui teknik fusi protoplas. Fusi protoplas merupakan suatu metode untuk menggabungkan dua atau lebih sel sehingga diperoleh kombinasi sel baru dengan bantuan aliran listrik atau zat kimia (Mariska dan Husni, 2002; (Kusumaningrum dan Zainuri, 2014; Kusumaningrum dan Zainuri 2015a; Kusumaningrum dan Zainuri 2015b; Kusumaningrum dan Zainuri 2015c). Karakter morfologi dari gabungan keduanya dibandingkan dengan induk menjadi faktor yang biasa digunakan oleh peneliti lain (Panaiotov et al., 2009). Namun, karakterisasi secara konvensional ini memiliki kemungkinan bahwa mikroalga yang memiliki 
fenotip sama teridentifikasi menjadi spesies yang sama, padahal keduanya belum tentu secara genetik memiliki kesamaan. Diperlukan karakterisasi dan identifikasi lebih lanjut menggunakan analisis secara molekuler. Karakteristik molekuler yang digunakan yaitu dengan melakukan analisis homologi basa DNA hasil sekuensing. Analisis homologi merupakan suatu teknik untuk melihat persamaan atau kekerabatan organisme di tingkat basa dan asam amino. Urutan basa juga digunakan untuk melakukan identifikasi atau determinasi terhadap suatu organisme yang belum diketahui atau baru ditemukan. Salah satu data molekuler yang dapat digunakan adalah sekuen DNA untuk gen 18SrDNA. Gen 18SrDNA dapat dipergunakan sebagai penanda molekuler dalam penyusunan klasifikasi filogenetik dan mengandung beberapa daerah yang memiliki sekuen yang terkonservasi dengan baik sehingga dapat digunakan untuk analisis filogenetik dengan membuat pohon filogenetik. Pohon filogenetik akan memperlihatkan hubungan kekerabatan mikroalga C. pyrenoidosa dan C. vulgaris. Penelitian ini bertujuan untuk melakukan karakterisasi dan identifikasi molekuler fusan dari proses fusi protoplas interspesies $C$. pyrenoidosa dan $C$. vulgaris menggunakan $18 \mathrm{SrDNA}$

\section{BAHAN DAN METODE Fusi Protoplas}

Mikroalga $C$. pyrenoidosa dan $C$. vulgaris diperoleh dari Balai Besar Pengembangan Budidaya Air Payau (BBPBAP) Jepara. Sel kedua induk dalam jumlah yang sama disentrifugasi untuk mendapatkan peletnya. Pelet dicuci dengan larutan penstabil osmotik. Pelet ditambah dengan enzim Lisozim $(160 \mu \mathrm{l}), 3 \% \mathrm{NaCl}(8 \mathrm{ml})$ dan 0,1 $\mathrm{M} \mathrm{CaCl}_{2}(800 \mu \mathrm{l})$, diinkubasi selama 20 menit pada suhu $35^{\circ} \mathrm{C}$ sehingga terbentuk protoplas. Protoplas disentrifugasi dengan kecepatan 6000 rpm selama 15 menit. Pelet $C$. pyrenoidosa dan $C$. vulgaris digabungkan, ditambahkan dengan PEG $6000(4800 \mu \mathrm{l}), 0,1 \mathrm{M} \mathrm{CaCl}_{2}(800 \mu \mathrm{l}), 2 \%$ glisin $(400 \mu \mathrm{l})$ dan diinkubasi pada suhu $30^{\circ} \mathrm{C}$ selama 30 menit. Sampel disentrifugasi dengan kecepatan $6000 \mathrm{rpm}$ selama 15 menit. Pelet dicuci dengan larutan penstabil osmotik. Sel rekombinan ditumbuhkan dalam air tawar dan air laut, diberi medium Walne. Sel dikultur dengan menggunakan aerasi dan iluminasi sebesar 3000 lux.

\section{Pengukuran $\beta$-Karoten}

Pengukuran $\beta$-karoten menggunakan metode modifikasi dari Hejazi et al. (2002). Sampel disentrifugasi dengan kecepatan $3000 \mathrm{rpm}$ selama 10 menit. Pelet ditambahkan isopropanol, divortek dan disentrifugasi dengan kecepatan 3000 selama 10 menit. Hasil sentrifugasi pada fase atas (tidak berwarna) diambil lalu diletakkan pada cuvet menggunakan UV-Vis Spektrofotometer. Pengukuran $\beta$-karoten dilakukan pada panjang gelombang 436. Pengukuran dilakukan menggunakan blanko isopropanol. Nilai absorbansi dan penghitungan $\beta$-karoten diketahui menggunakan rumus menurut metode AOAC (1995):

$$
\mathrm{Abs}=2-\log \mathrm{T}
$$

Keterangan:

Abs : Nilai absorbansi

$\mathrm{T} \quad$ : Transmitent yang diperoleh

$\beta$-karoten $(\mu \mathrm{g} / \mathrm{ml})$ diperoleh dengan menggunakan rumus:

$\beta$-karoten $=(\operatorname{Abs} x \lambda):(196 \times 1 \times\{($ volume awal:volume akhir $)\}$

Keterangan:

Abs : Nilai absorbansi

$\lambda$ : Panjang gelombang yang digunakan $(436 \mathrm{~nm})$

196 : Koefisien ekstinksi $\beta$-karoten

1 : Ukuran cuvet yang digunakan

\section{Isolasi DNA Metode Modifikasi CTAB}

Isolasi DNA menggunakan metode modifikasi CTAB (Roger and Bendich, 1994). Sampel disentrifugasi dengan kecepatan 10.000 rpm selama 5 menit. Pelet ditambahkan dengan buffer CTAB ekstraksi dingin $(500 \mu \mathrm{l})$ sebagai deterjen dan dihancurkan dengan mortar di atas ice gel sampai hancur dinding selnya. Buffer CTAB ditambahkan kedalam sampel $(500 \mu \mathrm{l})$ dan diinkubasi pada suhu $65^{\circ} \mathrm{C}$ selama 90 menit. Sampel ditambahkan kloroform:isoamil alkohol 
$(450 \mu \mathrm{l})$ dan sentrifugasi pada kecepatan 10.000 rpm selama 2 menit. Supernatan ditambahkan RNAse A $(5 \mu \mathrm{l})$ dan diinkubasi pada suhu $30^{\circ} \mathrm{C}$ selama 30 menit. Sampel ditambahkan dengan isopropanol dingin $(600 \mu \mathrm{l})$ dan diinkubasi pada suhu $-20^{\circ} \mathrm{C}$ selama overnight. Sampel disentrifugasi pada kecepatan $10.000 \mathrm{rpm}$ selama 5-10 menit dan terbentuk endapan putih. Pelet dicuci dengan $76 \%$ etanol

$(800 \mu \mathrm{l})$ dan Sodium Asetat $(100 \mu \mathrm{l})$, disentrifugasi pada kecepatan 10.000 rpm selama 5 menit. Pelet dicuci dengan $70 \%$ etanol $(100 \mu \mathrm{l})$ dan disentrifugasi pada kecepatan $10.000 \mathrm{rpm}$ selama 5 menit. Sisa etanol dibuang dan tersisa endapan putih untuk dikeringanginkan selama overnight. DNA yang terbentuk ditambah dengan buffer TE $\mathrm{pH} 8$ (50$100 \mu \mathrm{l})$ dan disimpan pada suhu $4^{\circ} \mathrm{C}$. Hasil isolasi DNA dilihat dengan elektroforesis gel agarosa $1 \%$.

\section{Gradient PCR 18SrDNA}

Bahan-bahan yang digunakan di short spin (microsentrifuge) untuk menurunkan larutan selama. Reaksi PCR dibuat dengan menambahkan buffer PCR 10x $(2,5 \mu \mathrm{l})$, dNTPs $(0,25 \mu \mathrm{l})$, primer 18S Chlorella forward 5' (CGG AGA RGG MGC MTG AGA) 3' (1,5 $\mu \mathrm{l})$, primer 18S Chlorella reverse 5' (GGG CGG TGT GTA CAA RGR) 3' $(1,5 \mu \mathrm{l})$, Taq Polymerase $\quad(0,25 \mu \mathrm{l})$, $\mathrm{ddH}_{2} \mathrm{O}(17 \mu \mathrm{l})$ dan template DNA $(2 \mu \mathrm{l})$. Semua bahan dicampur dan dimasukkan kedalam mesin gradient PCR untuk mendapatkan optimasi suhu annealing. Program PCR terdiri dari denaturasi awal pada suhu $94^{\circ} \mathrm{C}$ (3 menit), dilanjutkan dengan 30 siklus yang terdiri dari denaturasi pada suhu $94^{\circ} \mathrm{C}$ (25 detik), annealing pada suhu $55-63^{\circ} \mathrm{C}(45$ detik), ekstensi pada suhu $72^{\circ} \mathrm{C}$ (50 detik), ekstensi akhir pada suhu $72^{\circ} \mathrm{C}$ (1 menit) dan hold pada suhu $4^{\circ} \mathrm{C}$. Sampel kemudian disimpan kedalam freezer.

\section{Pendeteksian Hasil Gradient PCR dengan Metode Elektroforesis}

Sampel hasil amplifikasi yang diperoleh ditambahkan loading dye $(2 \mu \mathrm{l})$ dan dimasukkan kedalam sumuran gel agarosa. Marker (100 bp DNA Ladder) dimasukkan kedalam sumuran gel agarosa dengan komposisi marker yaitu loading dye $(1 \mu \mathrm{l})$, marker $(4 \mu \mathrm{l})$ dan akuades $(5 \mu \mathrm{l})$. Marker ditambahkan kedalam gel agarosa pada bagian sumuran paling ujung. Buffer TAE ditambahkan kedalam tangki sampai seluruh gel terendam. Elektroforesis dijalankan (dilakukan running) pada 100 Volt selama 20 menit. Setelah selesai running, gel agarosa dikeluarkan dan diletakkan di atas UV transluminator. UV transluminator dinyalakan dan pita-pita DNA yang tervisualisasi diamati.

\section{Sekuensing DNA}

Fragmen DNA selanjutnya disekuensing untuk melihat urutan basa DNA pada mikroalga $C$. pyrenoidosa dan $C$. vulgaris menggunakan mesin sekuensing ABI PRISM Mode 310 version 3.0. Hasil sekuensing DNA fusan dianalisis homologi basanya dengan memanfaatkan informasi sekuen DNA yang tersedia di dalam pusat data Genebank (http:/www/ncbi.nlm.nih.gov) menggunakan (Basic Local Alignment Search Tool nukleotide) BLASTn dan hubungan kekerabatan dengan spesies lain diidentifikasi melalui program MEGA 5.2 (Molecular Evolutionary Genetic Analysis) untuk pembuatan pohon filogenetik.

\section{RESULT AND DISCUSSION}

Hasil Fusi Protoplas $C$. pyrenoidosa dan $C$. vulgaris

Pembentukan protoplas $C$. pyrenoidosa dan C. vulgaris ditandai dengan pecahnya dinding sel akibat pemberian enzim Lisozim. Hasil pengamatan memperlihatkan bentuk protoplas $C$. pyrenoidosa dan $C$. vulgaris yang utuh serta membulat (spherik). Pemecahan dinding sel dapat dilihat pada Gambar 1 yang diperoleh dari hasil pengamatan secara mikroskopis. . Sel yang telah kehilangan dinding selnya akan membentuk protoplas. Gerken et al. (2012) menyatakan bahwa enzim Lisozim dapat memecah dinding sel Chlorella lebih optimal dibandingkan dengan enzim yang lain dan dapat mendegradasi di permukaan luar dinding sel. 


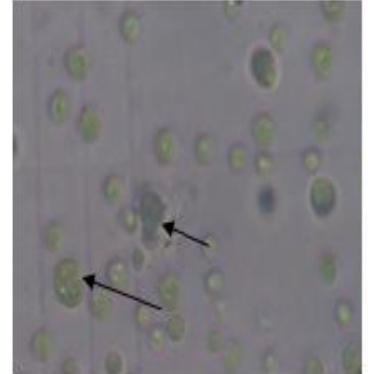

(A)

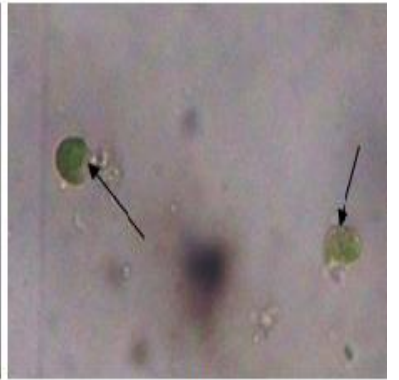

(B)
Gambar 1. Pemecahan dinding sel Chlorella pyrenoidosa (A) dan Chlorella vulgaris (B) (400x).

Hasil isolasi protoplas selanjutnya digunakan untuk fusi melalui penggabungan dua atau lebih sel. Fusi yang terjadi pada kedua protoplas ini dilihat dengan terbentuknya agregat protoplas. Penggabungan beberapa protoplas diperoleh karena adanya penggunaan PEG 6000 yang berperan sebagai penginduksi fusi, karena PEG menjadi jembatan antara dua protoplas atau lebih sehingga akan terjadi agregasi protoplas. Fusan terbentuk di hari keempat setelah dilakukan regenerasi kembali dengan jumlah sel pada media air tawar sebesar $8,4 \times 10^{5} \mathrm{sel} / \mathrm{ml}$ dan air laut sebesar $5 \times 10^{5} \mathrm{sel} / \mathrm{ml}$. Hal ini menunjukkan terjadinya regenerasi dinding sel protoplas. Kim et al. (2009), menyatakan bahwa saat sel mengalami kerusakan secara alami, sel mampu memperbaiki kerusakan tersebut dengan menambahkan protein dan polisakarida untuk mencegah kerusakan sel.

Hasil kultivasi fusan yang telah dikulturkan dengan dua media berbeda yaitu air tawar dan air laut memperlihatkan beberapa karakter yang berbeda dalam jumlah pertumbuhannya. Karakter yang terlihat yaitu bahwa fusan $C$. pyrenoidosa dengan C. vulgaris yang dihasilkan lebih banyak hidup di media air tawar, sedangkan fusan yang tumbuh pada media air laut memiliki jumlah sel yang sedikit (Gambar 2). Fusan yang dihasilkan lebih banyak hidup di air tawar, tetapi tidak selalu karakter fusan yang terbentuk lebih dominanC. pyrenoidosa karena posisi protoplas walaupun sudah mempunyai dinding sel masih diperlukan aklimatisasi dimana adanya dukungan dari kondisi air laut tersebut. Kondisi pada air tawar ternyata lebih memfasilitasi untuk terjadinya proses aklimatisasi, karena fusan yang lebih dominan di air laut apabila diletakkan pada air tawar lebih susah beradaptasi dibandingkan dengan fusan yang di air tawar dan diletakkan di air tawar juga.

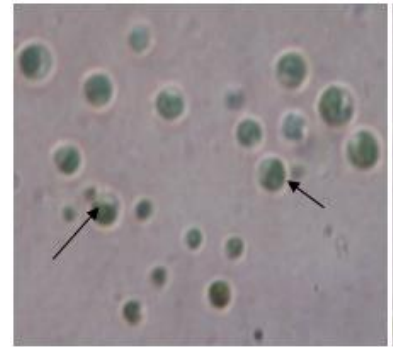

(A)

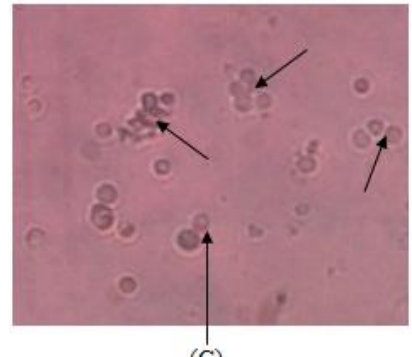

(C)

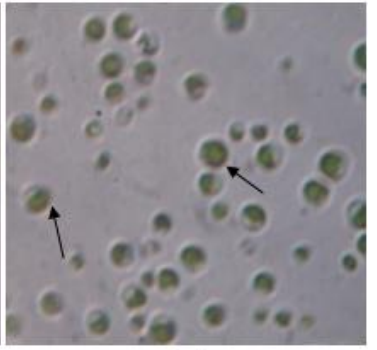

(B)

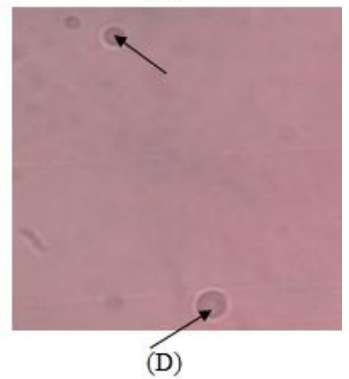

Gambar 2. Pengamatan mikroskopis induk C. pyrenoidosa (A); induk C. vulgaris (B) perbesaran 1000x dan fusan hasil fusi protoplas interspesies antara $C$. pyrenoidosa dengan $C$. vulgaris pada air tawar (C); air laut (D) perbesaran 400x.

Hasil pengamatan juga menunjukkan bahwa adanya perbedaan bentuk antara fusan yang beradaptasi pada air tawar dengan air laut (Gambar 2). Sel fusan pada air tawar berbentuk seperti bulat lonjong dan cenderung bergerombol, sedangkan pada air laut berbentuk bulat telur dan tidak bergerombol. Sel rekombinan yang bergerombol biasanya dikarenakan sel masih beradaptasi terhadap keadaan lingkungan yang jelek atau lingkungan ekstrim, apabila lingkungan sudah mendukung dan mampu beradaptasi maka sel tersebut akan memisah atau menjadi tunggal. Berdasarkan hasil pengamatan, fusan tersusun oleh beberapa protoplas dari $C$. pyrenoidosa dan $C$. vulgaris yang berkisar antara 3-4 protoplas/fusan dengan ukuran sel yang lebih besar dari kedua induknya. Protoplas yang bergabung dengan kisaran antara dua atau lebih protoplas menjadi suatu individu baru yang mampu bertahan 
hidup dan berkembang dinamakan sebagai hasil dari fusi protoplas (Suryowinoto, 2000).

Perbedaan lainnya dilihat dari pertumbuhan sel induk dan fusan. Pertumbuhan ditandai dengan bertambah besarnya ukuran sel atau bertambah banyaknya jumlah sel. Isnansetyo dan Kurniastuty (1995) memaparkan bahwa laju pertumbuhan adalah pertambahan jumlah sel dalam periode tertentu. Rata-rata jumlah sel $C$. pyrenoidosa dan C. vulgaris sebelum dilakukan fusi protoplas secara berturut-turut yaitu $3,6 \times 10^{6} \mathrm{sel} / \mathrm{ml}$ dan $2,6 \times 10^{6} \mathrm{sel} / \mathrm{ml}$. Pertumbuhan fusan mengalami penurunan dibandingkan dengan masing-masing induk dimana jumlah yang dihasilkan dari fusan tidak melebihi induknya. Sel fusan pada air tawar memiliki rata-rata sel sekitar $6,7 \times 10^{5} \mathrm{sel} / \mathrm{ml}$, sedangkan pada air laut hanya memiliki sel sekitar $2,3 \times 10^{5} \mathrm{sel} / \mathrm{ml}$.

Frekuensi keberhasilan hasil fusi protoplas secara interspesies antara $C$. pyrenoidosa dengan C. vulgaris yang dibandingkan dengan sel induk pada media air tawar sebesar $21 \%$ dan media air laut sebesar 6\%. Rendahnya frekuensi keberhasilan hasil fusi dapat dikarenakan dari fusi protoplas yang dilakukan dengan dua spesies yang berbeda. Mariska dan Husni (2002), menyatakan bahwa keberhasilan fusi antara lain ditentukan oleh metode isolasi protoplas, metode yang digunakan untuk fusi, bahan kimia yang digunakan untuk menginduksi berikut konsentrasinya, waktu inkubasi atau fusi, media kultur, media pengenceran sel dan media regenerasi. Semakin banyak protoplas yang terisolasi maka semakin tinggi tingkat keberhasilan fusi. Namun keberhasilan tersebut ditentukan oleh bahan yang digunakan untuk isolasi protoplas.

Pertumbuhan sel fusan tidak seperti dengan induknya dikarenakan bahwa fusan terdiri dari penggabungan dua atau lebih sel yang mengakibatkan regenerasi sel berjalan lambat. Proses pertumbuhan fusan dalam air tawar dan air laut, secara bertahap akan menurun jumlah selnya setelah mencapai pertumbuhan yang stabil. Hal ini dikarenakan nutrisi yang menipis dan akumulasi metabolit fusan dapat menghambat pertumbuhan, sehingga pertumbuhannya akan berhenti setelah mencapai waktu tertentu.

Fusan yang telah diperoleh dapat menghasilkan karotenoid seperti pada masing- masing kedua induknya. Salah satu karotenoid yang terkandung di dalamnya yaitu $\beta$-karoten dengan jumlah $0,01 \mu \mathrm{g} / \mathrm{ml}$ untuk fusan air tawar dan $0,04 \mu \mathrm{g} / \mathrm{ml}$ untuk fusan air laut. Hasil $\beta$ Karoten menunjukkan bahwa pada induk $C$. pyrenoidosa tidak menghasilkan $\beta$-karoten dan induk $C$. vulgaris memiliki $\beta$-karoten sebesar $0,61 \mu \mathrm{g} / \mathrm{ml}$. Hasil $\beta$-karoten pada fusan air tawar dan air laut lebih didominasi oleh induk $C$. vulgaris, karena pada induk $C$. pyrenoidosa tidak menghasilkan $\beta$-karoten. Kandungan $\beta$-karoten yang terdapat pada induk $C$. vulgaris lebih tinggi dibandingkan pada fusan. Sesuai dengan hasil penelitian Yunanto $d k k$. (2013), dimana induk Dunaliella salina menghasilkan $\beta$-karoten lebih besar yaitu $2 \mu \mathrm{g} / \mathrm{ml}$ dan induk C.pyrenoidosa sebesar $0,1 \mu \mathrm{g} / \mathrm{ml}$, sedangkan fusan air laut menghasilkan $\beta$-karoten sebesar $0,6 \mu \mathrm{g} / \mathrm{ml}$ dan fusan air tawar sebesar $0,8 \mu \mathrm{g} / \mathrm{ml}$. Goodwin (1984) menyatakan bahwa produksi $\beta$-karoten Chlorella terjadi bersamaan dengan sintesis klorofil selama fase pertumbuhan logaritmik, sehingga konsentrasinya menurun ketika jalur karotenogenik diaktifkan. Gouveia et al. (1996), menyatakan bahwa apabila jalur karotenogenik diaktifkan, maka terjadinya transformasi oksidatif dari $\beta$-karoten menjadi canthaxanthin dan jalur hydroxylative menuju zeaxanthin/lutein.

\section{Hasil Isolasi DNA Fusan dan Induk}

Hasil isolasi DNA fusan dan induk dikarakterisasi secara kualitatif dengan divisualisasikan menggunakan elektroforesis pada gel agarosa 1\%. Hasil isolasi DNA dengan menggunakan metode modifikasi CTAB mampu mengisolasi DNA C. pyrenoidosa dan $C$. vulgaris dengan kualitas baik yang ditunjukkan pada hasil elektroforesis dimana adanya pemisahan secara jelas dan ketebalan pita DNA yang beragam (Gambar 3). 


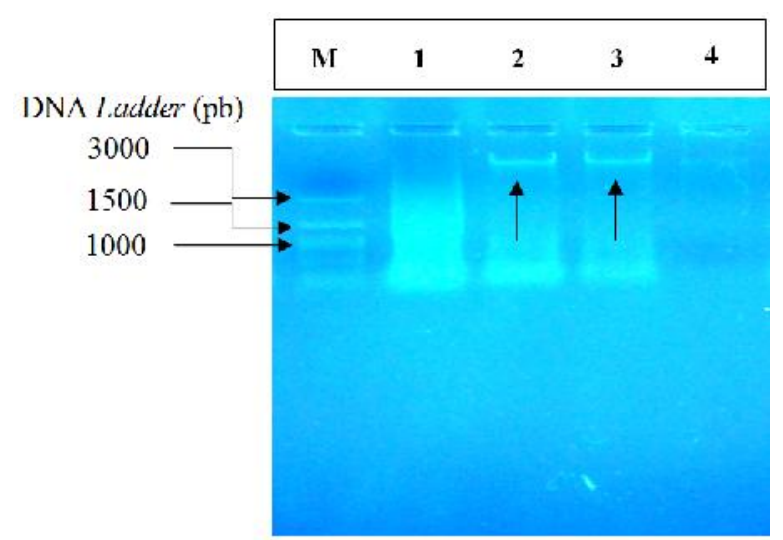

Gambar 3. Hasil pengecekan kualitas DNA genom. Marker DNA Ladder 100bp (M); induk Chlorella vulgaris (1); induk Chlorella pyrenoidosa (2); fusan air tawar (3) dan fusan air laut (4).

Pita yang ditunjukkan pada Gambar 3 kolom kedua dan ketiga berukuran di atas $3000 \mathrm{pb}$ menyatakan banyaknya jumlah DNA yang diperoleh, sedangkan pada kolom pertama dan keempat tidak terlihat adanya pita DNA, karena adanya smear disepanjang jalur yang menunjukkan pita DNA terfragmentasi selama proses isolasi. Meskipun demikian, DNA tersebut tergolong masih baik untuk digunakan pada kegiatan analisis selanjutnya.

Tabel 1. Konsentrasi dan Kemurnian DNA.

\begin{tabular}{lccc}
\hline \multirow{2}{*}{ Sampel } & $\begin{array}{c}\text { Konsentrasi } \\
(\mu g \mathrm{ml})\end{array}$ & \multicolumn{2}{c}{ Kemumian } \\
\cline { 3 - 4 } & & $\left(\mathrm{A}_{200} / \mathrm{A}_{200}\right)$ & $\left(\mathrm{A}_{20} / \mathrm{A}_{200}\right)$ \\
Induk Chlorella pyrenoidosa & 277.5 & 1.888 & 1.300 \\
Induk Chiorella vulgaris & 589.5 & 1.803 & 1.510 \\
Fusan Air Tawar & 279.5 & 1.896 & 1.532 \\
Fusan Air Laut & 35 & 1.750 & 0.795 \\
\hline
\end{tabular}

Konsentrasi DNA bisa diukur dari nilai absorbansi pada $\lambda 260 \mathrm{~nm}$, sedangkan kemurniannya diperoleh dengan melihat rasio $\mathrm{A}_{260}: \mathrm{A}_{280}$ (Tabel 1). Hasil isolasi DNA genom menunjukkan bahwa masing-masing sampel telah murni dan DNA yang didapatkan mempunyai kualitas yang baik. Hasil isolasi DNA yang diperoleh tidak atau sedikit terkontaminasi dengan protein atau RNA, karena ratio $\mathrm{A}_{260 / 280}$ mempunyai nilai 1,8 yang terdapat pada induk $C$. vulgaris,
C. pyrenoidosa dan fusan air tawar, walaupun adanya sedikit perbedaan nilai ratio pada fusan air laut yaitu 1,7. Molekul DNA dikatakan murni jika rasio kedua nilai tersebut berkisar antara 1,8-2,0. Kontaminasi protein dan bahan organik lainnya ditandai dengan rendahnya nilai rasio $\mathrm{A}_{260} / \mathrm{A}_{280}$ $(<1,8)$, sebaliknya kontaminasi fenol ditandai dengan tingginya nilai rasio tersebut $(>2,0)$ (Sambrook et al., 1989., Linacero et al., 1998). Nilai kemurnian DNA mempengaruhi keberhasilan amplifikasi, karena nilai kemurnian yang baik pada saat dilakukan visualisasi di bawah sinar UV, maka pita DNA yang terbentuk akan terlihat lebih jelas. Menurut Sambrook and Russell (2001), kisaran angka tersebut telah memenuhi persyaratan yang dibutuhkan dalam analisis molekuler lebih lanjut.

\section{Hasil Gradient PCR 18SrDNA Fusan dan Induk}

Hasil isolasi DNA yang telah dielektroforesis dan menghasilkan pita DNA yang berkualitas baik dilanjutkan dengan proses PCR. Optimasi PCR dilakukan menggunakan induk $C$. pyrenoidosa, induk $C$. vulgaris dan fusan air tawar. Fusan air laut tidak diikutsertakan dalam optimasi PCR, karena pada saat visualisasi hasil isolasi DNA tidak terlihat adanya pita DNA, sehingga hanya fusan air tawar yang digunakan untuk analisis selanjutnya. Optimasi kondisi PCR menggunakan mesin gradient PCR dengan beberapa suhu annealing bertujuan untuk memperoleh pita hasil amplifikasi yang baik dan spesifik.

Hasil amplifikasi dengan beberapa suhu annealing dapat dilihat pada Gambar 4. Suhu annealing yang digunakan pada mesin gradient PCR yaitu $55,2^{\circ} \mathrm{C} ; 57,2^{\circ} \mathrm{C} ; 59,9^{\circ} \mathrm{C} ; 61,7^{\circ} \mathrm{C}$ dan $63^{\circ} \mathrm{C}$ untuk fusan air tawar dan induk $C$. pyrenoidosa, sedangkan $C$. vulgaris menggunakan suhu annealing diantaranya $55^{\circ} \mathrm{C} ; 56,5^{\circ} \mathrm{C} ; 59,5^{\circ} \mathrm{C}$; $61,7^{\circ} \mathrm{C}$ dan $63^{\circ} \mathrm{C}$. Suhu denaturasi yang digunakan ketiga sampel yaitu $94^{\circ} \mathrm{C}$ dan suhu ekstensi $72^{\circ} \mathrm{C}$.

Hasil visualisasi optimasi suhu annealing (Gambar 4.a) menunjukkan bahwa pada suhu $59,9^{\circ} \mathrm{C}$ terbentuk pita DNA yang paling tebal dibandingkan dengan variasi suhu lainnya $\left(55,2^{\circ} \mathrm{C}\right.$; $57,2^{\circ} \mathrm{C} ; 61,7^{\circ} \mathrm{C}$ dan $63^{\circ} \mathrm{C}$ ) dan menghasilkan 1 pita fragmen DNA dengan ukuran sekitar $\pm 1500 \mathrm{pb}$. Kondisi amplifikasi dengan suhu annealing yang 
optimal untuk induk C. pyrenoidosa (Gambar 4.b) yaitu pada suhu $57,2^{\circ} \mathrm{C} ; 59,9^{\circ} \mathrm{C} ; 61,7^{\circ} \mathrm{C}$ dan $63^{\circ} \mathrm{C}$ dengan ukuran pita DNA sekitar $\pm 1600 \mathrm{pb}$, sedangkan suhu annealing optimal untuk induk $C$. vulgaris (Gambar 4.c) terdapat pada suhu $59,5^{\circ} \mathrm{C}$, suhu $61,6^{\circ} \mathrm{C}$ dan suhu $63^{\circ} \mathrm{C}$ dengan masing-masing ukuran pita DNA sekitar $\pm 1250 \mathrm{pb}$.

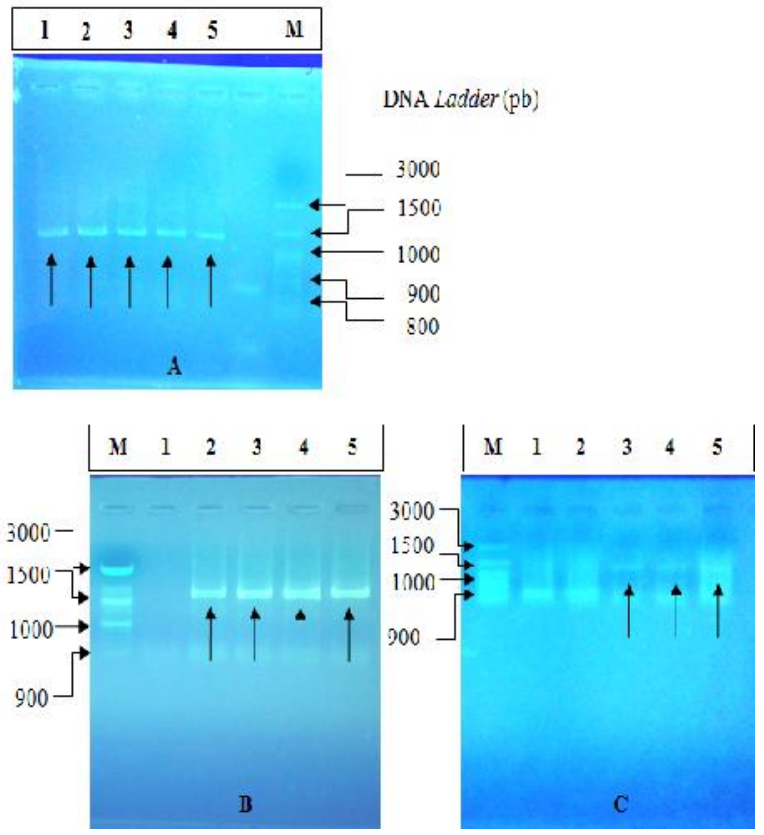

Gambar 4. Hasil gradient PCR dengan primer $18 \mathrm{~S}$ Chlorella. Fusan air tawar (A) suhu $55,2^{\circ} \mathrm{C}(1) ; \quad$ suhu $57,2^{\circ} \mathrm{C}(2) ; \quad$ suhu $59,9^{\circ} \mathrm{C}(3)$; suhu $61,7^{\circ} \mathrm{C}(4)$; suhu $63^{\circ} \mathrm{C}(5)$; marker DNA Ladder 100bp (M). Induk Chlorella pyrenoidosa (B) suhu $55,2^{\circ} \mathrm{C}(1) ; \quad$ suhu $57,2^{\circ} \mathrm{C}(2) ; \quad$ suhu $59,9^{\circ} \mathrm{C}(3)$; suhu $61,7^{\circ} \mathrm{C}(4)$; suhu $63^{\circ} \mathrm{C}(5)$. Induk Chlorella vulgaris (C) suhu $55^{\circ} \mathrm{C}(1)$; suhu $56,5^{\circ} \mathrm{C}(2)$; suhu $59,5^{\circ} \mathrm{C}(3)$; suhu $61,6^{\circ} \mathrm{C}(4)$; suhu $63^{\circ} \mathrm{C}(5)$.

Faktor yang perlu diperhatikan saat optimasi PCR selain pada suhu annealing adalah primer. Primer yang kurang spesifik dapat mengakibatkan kesalahan amplifikasi DNA target. Primer yang digunakan untuk mengamplifikasi DNA $C$. pyrenoidosa dan $C$. vulgaris yaitu primer $18 \mathrm{~S}$ Chlorella forward 5' (CGG AGA RGG MGC MTG AGA) 3' dan primer 18S Chlorella reverse 5' (GGG CGG TGT GTA CAA RGR) 3'. Keberhasilan isolasi dan amplifikasi DNA dengan
PCR bergantung pada konsentrasi DNA template yang cukup, primer dan temperatur annealing (Nugroho $d k k ., 2013$ ).

Pemilihan suhu annealing berkaitan dengan melting temperature $(\mathrm{Tm})$ primer yang digunakan. Primer $18 \mathrm{~S}$ Chlorella memiliki TM $58^{\circ} \mathrm{C}$. Perhitungan rumus $\mathrm{Tm}=(\mathrm{G}+\mathrm{C}) \times 4+(\mathrm{A}+\mathrm{T}) \times 2$ (Fatchiyah et al., 2011). Suhu annealing yang digunakan dapat dihitung berdasarkan $(\mathrm{Tm}-5)^{\circ} \mathrm{C}$ sampai dengan $(\mathrm{Tm}+5)^{\circ} \mathrm{C}$. Menurut Sambrook and Russell (2001), menyatakan bahwa suhu annealing yang terlalu tinggi menyebabkan primer sulit untuk menempel pada cetakan, sehingga menjadi kurang optimal, sedangkan suhu annealing yang terlalu rendah menyebabkan primer berlekatan diberbagai tempat, sehingga hasil PCR menjadi tidak spesifik.

\section{Hasil Karakterisasi Molekuler Fusan menggunakan 18SrDNA terhadap Kedua Induk $C$. prenoidosa dan $C$. vulgaris \\ Hasil karakterisasi menggunakan hasil} sekuensing basa fusan hasil fusi protoplas antara $C$. pyrenoidosa dengan $C$. vulgaris. Sekuensing DNA mikroalga dilakukan menggunakan primer Chlorella 18S Forward. Sekuensing DNA menghasilkan sekuen DNA yang berukuran sekitar $632 \mathrm{pb}$ untuk fusan air tawar, sedangkan induk C. pyrenoidosa menghasilkan sekuen DNA berukuran $580 \mathrm{pb}$. Meskipun hasil sekuensing yang diperoleh tidak terlalu panjang dikarenakan keterbatasan oleh mesin sekuensing, namun Hillis and Davis (1988) menyatakan bahwa ukuran pendek dari ribosomal DNA sudah dapat digunakan untuk analisis homologi dan filogenetik. Pembacaan sekuensing oleh mesin yang baik berkisar antara $500 \mathrm{pb}$.

Hasil analisis homologi urutan basa hasil sekuensing fusan air tawar menggunakan program Basic Local Alignment Search Tool (BLAST) pada situs NCBI memperlihatkan homologi sebesar 93\% dari 227 basa (Gambar 5). Berdasarkan hasil tersebut kita dapat melihat perbedaan dan kesamaan urutan basa (similarity) fusan air tawar dengan sekuen lain pada pusat data GeneBank. Menurut Widayat dan Subositi (2009), BLAST adalah program yang digunakan untuk menentukan similaritas antar sekuen dan membandingkan satu input sekuen dengan semua 
sekuen yang ditemukan dalam database. Hasil pensejajaran (alignment) antara fusan air tawar dengan induk C. vulgaris dari GeneBank, dimana terdapat persamaan 210 basa diantara 227 basa. Gap yang ditunjukkan dengan anak panah memperlihatkan adanya insersi basa sebanyak 2 basa pada fusan dan 1 basa pada induk (Gambar $5)$.

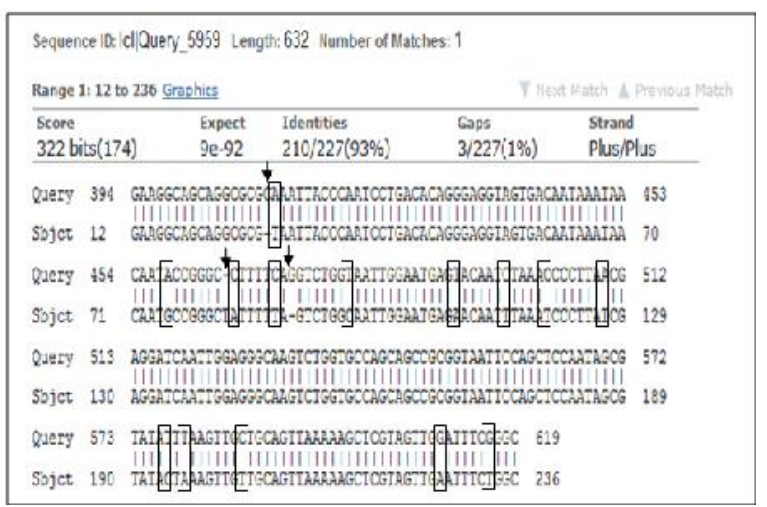

Gambar 5. Hasil analisis homologi sekuen fusan air tawar dengan induk Chlorella vulgaris dari GeneBank menggunakan BLASTn.

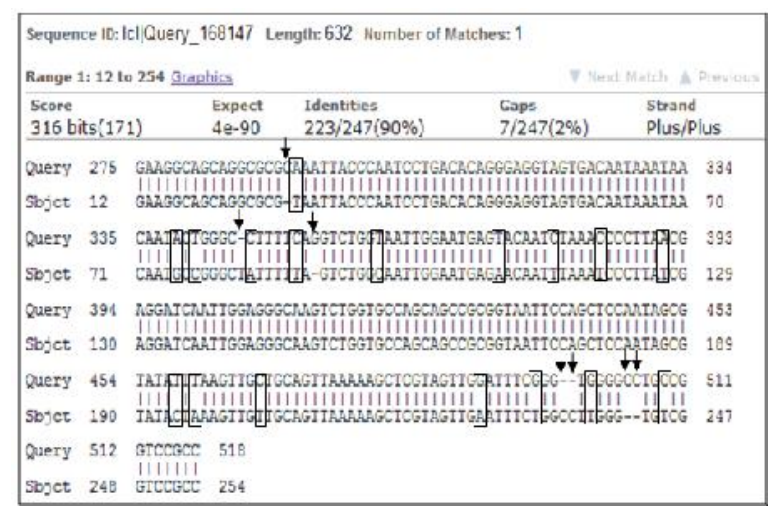

Gambar 6. Hasil analisis homologi sekuen fusan air tawar dengan induk Chlorella pyrenoidosa dari GeneBank menggunakan BLASTn.

Gambar 6 juga memperlihatkan homologi sebesar 90\% dari 247 basa dengan induk C. pyrenoidosa. Hasil pensejajaran antara fusan air tawar dengan induk C. pyrenoidosa dari GeneBank terdapat persamaan 223 basa diantara 247 basa. Gap yang ditunjukkan dengan anak panah memperlihatkan adanya insersi basa sebanyak 4 basa pada fusan dan 3 basa pada induk. Gap merupakan garis putus-putus (--) yang berada diantara urutan basa. Berdasarkan hasil pensejajaran diketahui bahwa fusan air tawar memiliki kemiripan dengan induk $C$. vulgaris dikarenakan homologi basa fusan dengan induk $C$. vulgaris lebih tinggi yaitu 93\%, sedangkan homologi basa fusan dengan induk $C$. pyrenoidosa sebesar $90 \%$.

Hasil yang diperoleh ditemukan adanya substitusi basa antara fusan air tawar dengan kedua induk dari GeneBank. Subtitusi basa pada fusan dengan induk $C$. vulgaris sebesar 14 basa. Bila A $\rightarrow \mathrm{C}, \mathrm{A} \rightarrow \mathrm{T}, \mathrm{C} \rightarrow \mathrm{A}, \quad \mathrm{C} \rightarrow \mathrm{G}, \mathrm{T} \rightarrow \mathrm{A}, \mathrm{T}$ $\rightarrow \mathrm{C}, \mathrm{G} \rightarrow \mathrm{C}$ dan $\mathrm{G} \rightarrow \mathrm{T}$, maka proses perubahan basa ini disebut transversi karena purin berubah menjadi pirimidin, sedangkan apabila $\mathrm{A} \rightarrow \mathrm{G}$, $\mathrm{G} \rightarrow \mathrm{A}, \mathrm{C} \rightarrow \mathrm{T}, \mathrm{T} \rightarrow \mathrm{C}$, maka disebut dengan transisi karena purin berubah menjadi purin. Hasil perhitungan substitusi basa menunjukkan bahwa fusan air tawar dengan induk $C$. pyrenoidosa dari GeneBank sebanyak 17 basa, terdiri dari 7 tranversi dan 10 transisi. Selain itu, substitusi basa pada fusan air tawar dengan induk $C$. vulgaris dari GeneBank terdapat 14 substitusi basa yang terdiri dari 7 tranversi dan 7 transisi. Perhitungan besarnya substitusi basa dilakukan untuk mengetahui kurun waktu terjadinya keragaman genetik yang berkaitan dengan perubahan basa yang terjadi.

\section{Hasil Identifikasi Molekuler Fusan menggunakan 18SrDNA}

Hasil identifikasi molekuler fusan dengan anggota Chlorophyta memperlihatkan bahwa fusan air tawar masuk kedalam satu kelompok dengan genus Chlorella yang ditunjukkan oleh pohon filogenetik hasil konstruksi dengan metode neighbor-joining tree (Gambar 7). Angka bootstrap 100 memperlihatkan bahwa pembentukan pohon evolusi yang diulang selama 100 kali menunjukkan bahwa semua ulangan tersebut memperlihatkan pohon yang sama dengan derajat kepercayaan $100 \%$. Pohon filogenetik yang diperoleh merupakan hasil identifikasi molekuler antara fusan air tawar dengan C. pyrenoidosa dan spesies mikroalga fotosintetik lainnya. Pohon filogenetik yang dihasilkan merupakan hasil pemilihan diantara beberapa metode yang diperkirakan paling mewakili 
hubungan antara fusan dengan mikroalga lainnya. Pembuatan pohon filogenetik dilakukan dengan menggunakan program MEGA 5.2 dan dikonstruksi menggunakan Neighbor-joining tree. Neighbor-joining tree dianggap mewakili hasil penelitian, karena akan memilih sekuen yang jika digabungkan akan memberikan estimasi terbaik dari panjang cabang yang paling dekat merefleksikan jarak yang nyata diantara sekuen.

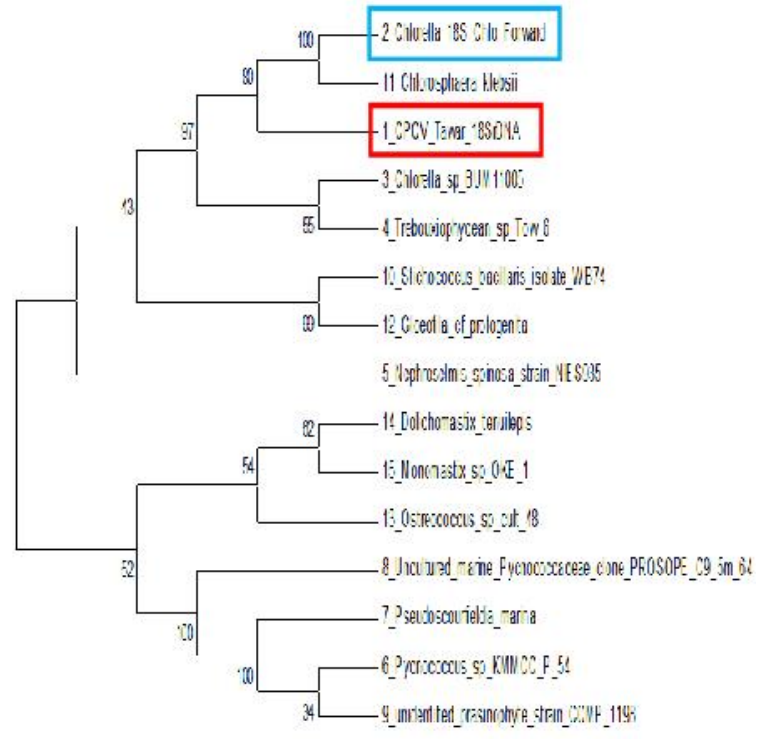

Gambar 7. Pohon filogenetik yang menggambarkan hubungan kekerabatan antara fusan air tawar (CPCV T 18SrDNA), induk Chlorella pyrenoidosa $18 \mathrm{~S}$ Chlorella dan sekuen lain dari GeneBank menggunakan model Neighbor-Joining.

Berdasarkan gambar di atas memperlihatkan bahwa fusan air tawar memiliki hubungan kekerabatan yang dekat dengan induk C. pyrenoidosa $18 \mathrm{~S}$ Chlorella dan Chlorosphaera klebsii. Kemiripan antara fusan air tawar dengan Chlorosphaera klebsii sebesar 91\%. Hubungan kekerabatan antara fusan air tawar dengan spesies lain sebagai pembanding dikarenakan masih berada dalam satu divisi yang sama yaitu kelompok Chlorophyta. Selain itu, kemiripan fusan air tawar dengan induk C. pyrenoidosa $18 \mathrm{~S}$ Chlorella diduga, karena memiliki sifat yang sama berdasarkan habitatnya seperti fusan air tawar dan induk $C$. pyrenoidosa yang dapat hidup pada media air tawar.
Pohon filogenetik yang diperoleh menggambarkan perubahan yang terjadi pada gen penanda tiap spesies. Semakin panjang suatu cabang, semakin banyak perubahan yang terjadi pada gen penanda, akibatnya spesies yang berada pada cabang tersebut dapat dikatakan lebih maju. Panjang masing-masing cabang mewakili jumlah perubahan yang terjadi pada karakter yang digunakan, sehingga karakter yang sangat mirip akan berdekatan dalam percabangan. Pohon filogenetik memberikan informasi tentang pengklasifikasian populasi berdasarkan hubungan evolusionernya, karena pada rekonstruksi pohon filogenetik, data molekul lebih banyak dipakai dan dianggap lebih stabil dalam proses evolusi dibandingkan dengan data morfologi.

\section{KESIMPULAN}

Karakterisasi molekuler fusan hasil fusi protoplas secara interspesies $C$. pyrenoidosa dan $C$ vulgaris menggunakan 18SrDNA memperlihatkan homologi urutan basa antara fusan air tawar dengan induk $C$. pyrenoidosa sebesar $90 \%$ dan induk C. vulgaris sebesar $93 \%$. Hasil identifikasi molekuler menunjukkan bahwa fusan air tawar berkerabat dengan induk $C$. pyrenoidosa dan mikroalga Chlorosphaera klebsii dengan kemiripan sebesar $91 \%$.

\section{DAFTAR PUSTAKA}

AOAC. 1995. Official Method of Analysis. AOAC, Inc, Washington DC.

Asni. 2000. Pengaruh Penambahan Serbuk Chlorella pyrenoidosa Strain Lokal (INK) terhadap Mutu Organoleptik dan Kimia Minuman Teh. Skripsi. Fakultas Perikanan dan Ilmu Kelautan Institut Pertanian Bogor, Bogor.

Fatchiyah, Arumingtyas, E.L., Widyarti, S., dan Rahayu, S. 2011. Biologi Molekular Prinsip Dasar Analisis. Erlangga. Jakarta.

Gerken, H.G., B, Donohoe and E.P. Knoshaug. 2012. Enzymatic Cell Wall Degradation of Chlorella vulgaris and Other Microalgae for Biofuels Production. J. Planta 237:239-253.

Goodwin, T.W. 1984. Biochemistry of Carotenoids, Vol. 2, $2^{\text {end }}$ ed. Chapman and Hall. London. 
Gouveia, L., Veloso, V., Reis, A., Fernandes, H., Novais, J., and Empis, J. 1996. Evolution of Pigment Composition in Chlorella vulgaris. J. Biores. Technol 57:157-163.

Hejazi, M.A., C. de Lamariere, J.M.S. Rocha, M. Vermue and J. Tramper. 2002. Selective Extraction of Carotenoids from Microalga Dunaliella salina with Retention of Viability. J. Biotechnol and Engineer 79(1):29-36.

Hillis, D.M., and S.K. Davis. 1988. Ribosomal DNA: Intraspesific Polymorphism, concerted evolution and phylogeny reconstruction. Syst. Zool 37:63-66.

Isnansetyo, A. dan Kurniastuty. 1995. Teknik Kultur Phytoplankton dan Zooplankton. Kanisius. Yogyakarta.

Kim, G.H., T.A. Klotchkova and Y, Kang. 2009. Life Without a Cell Membrane: Regeneration of Protoplasts from Disintegrated Cells of the Marine Green Alga Bryopsis plumosa. J. of Cell Sci 114.

Kusumaningrum, H. P. and Zainuri. M. 2013. Application of rich carotenoid natural food supplement from recombinant interspecies protoplast fusion on Penaeus monodon fab. post-larvae. Indonesian Journal of Marine Sciences. ISSN 0853-7291. 18(3):143-149

Kusumaningrum, H. P. and Zainuri. M. 2014. Optimization and Stability of Total Pigments Production of Fusan from Protoplast Fusion of Microalgae Dunaliella and Chlorella in vivo: Attempts on Production of Sustainable Aquaculture Natural Food. Int. J. of Marine and Aquatic Resource Conservation and Co-existence (IJMARCC Vol 1(1):1-5, October 2014, ISSN : 2406-9094

Kusumaningrum, H. P. and Zainuri. M. 2015a. Detection pf Bacteria and Fungi Associated with Penaeus monodon Postlarvae Mortality. International Journal Procedia Environmental Sciences. 23: 329-337.

Kusumaningrum, H. P. and Zainuri. M. 2015b. Molecular Characterization of Dunaliella salina and Chlorella vulgaris Fusant using 18SrDNA Gene. Journal Teknologi (Science and Engineering) 75:1 (2015) 1-6 | www. jurnalteknologi.utm.my | eISSN 2180-3722 |

Kusumaningrum, H. P. dan Zainuri. M. 2015c. Karakterisasi Dominan Fusan dari Mikroalga Dunaliella salina dan Chlorella vulgaris menggunakan primer 18SrRNA untuk mengembangkan Produksi Karotenoid. Seminar Nasiona Biologi. Universitas Diponegoro. Agustus

Linacero, R., J. Rueda and A.M. Vazquez. 1998. Quantification of DNA. Pages 18-21 in Karp, A., P.G. Isaac, and D.S. Ingram (Eds.) Molecular Tools for Screening Biodiversity: Plants and Animals. Chapman and Hall. London, Weinheim, New York, Tokyo, Melbourne, Madras.

Mariska, I. dan A. Husni. 2002. Perbaikan Sifat Genotipe melalui Fusi Protoplas pada Tanaman Lada, Nilam dan Terung. Balai Besar Penelitian dan Pengembangan Bioteknologi dan Sumberdaya Genetik Pertanian, Bogor.

Maruyama, I., et al. 1997. Application of Unicellular Algae Chlorella vulgaris for the Mass-Culture of Marine Rotifer Brachionus. J. Hydrobiol 358:133-138.

Nugroho, T.T., Rambe, E., Dewi, A., Fitri, R.M., Sepryani, H., Restuhadi, F., dan Haryani, Y. 2013. Optimasi Isolasi dan Amplifikasi ITS DNA Ribosomal Fungi Karbolitik Isolat Zona Inti Cagar Biosfer Giam Siak KecilBukit Batu. Prosiding Semirata FMIPA Unila 407-412.

Panaiotov, S., Evstatieva, Y., Ilieva, S., Levtorova, V., Brankova, N., Nikolova, D., Ivanova, A., Stefanova, V., Tankova, K., and Atev, A. 2009. Quantitative Assessment of the Dominant Genome in Fusant Cultures. $J$. Biotechnol. \& Biotechnol EQ 23.

Roger, S.O. and A.J. Bendich. 1994. Extraction of Total Cellular DNA from Plant, Algae and Fungi. Molecular Biology Manual.

Sambrook, J., Fritsch, E.F., Maniatis, T. 1989. Molecular Cloning: A Laboratory Manual, second ed. Cold spring Harbor, New York.

Sambrook, J. and D.W. Russell. 2001. Molecular Cloning: A Laboratory Manual Third Edition. Cold Spring Harbor Laboratory Press, New York. 
Suryowinoto, M. 2000. Pemuliaan Tanaman secara In Vitro. Kanisius, Yogyakarta.

Widayat, T. dan Subositi, D. 2009. Kekerabatan Filogenetik Buah Makasar (Brucea javanica) Berdasarkan Gen Ribulosa-1,5bifosfat Karboksilase/Oksigenase. Balai Besar Penelitian dan Pengembangan Tanaman Obat dan Obat Tradisional, Badan
Litbangkas, Departemen Kesehatan. Jawa Tengah.

Yunanto, Y., Kusumaningrum, H.P., dan Pujiyanto, S. 2013. Fusi Protoplas Interspesies Chlorella pyrenoidosa dan Dunaliella salina. J. Sains dan Matematika 21(1):25-30. 